\title{
Variation in Occurrence of Dematiaceous Hyphomycetes on Forage Bermudagrass over Years, Sampling Times, and Locations
}

\author{
R. G. Pratt \\ United States Department of Agriculture-Agricultural Research Service, Waste Management \& Forage Research Unit, Mississippi State \\ 39762. \\ Accepted for publication 7 June 2005.
}

\begin{abstract}
Pratt, R. G. 2005. Variation in occurrence of dematiaceous hyphomycetes on forage bermudagrass over years, sampling times, and locations. Phytopathology 95:1183-1190.

Leaf samples of forage bermudagrass with symptoms of infection by species of Bipolaris, Curvularia, and Exserohilum (dematiaceous hyphomycetes) were collected from three swine waste application sites in Mississippi at eight sampling times during each of 3 years. Samples were assayed for pathogens by observing sporulation on plated leaf tissue. Among 3,600 leaves assayed, eight species of the three genera were observed. Features and criteria for the practical identification of species on plated leaf samples are described. Sporulation by dematiaceous hyphomycetes was observed on $97 \%$ of leaves; a single pathogen was observed on $20 \%$ and two to five pathogens were observed on $77 \%$ of leaves. Distributions of leaves among classes with one to five pathogens per leaf, for sites within years, always differed significantly $(P=0.01)$ from a Poisson distribution and usually included fewer leaves than expected with four or five pathogens. Significant $(P=0.05)$ variation in

frequencies of occurrence of pathogens among 72 samples of 50 leaves each was attributed to pathogen species, sampling times, and speciestime interactions. Exserohilum rostratum, Curvularia lunata, and Bipolaris cynodontis were the most frequent pathogens across years and sites; B. spicifera and C. geniculata were intermediate; and B. hawaiiensis, $B$. sorokiniana, and $B$. stenospila were least frequent. For the five most common pathogens, significant differences in frequency among locations were commonplace. Six pathogens exhibited significant $(P=0.05)$ positive and negative correlations with others in overall frequencies of occurrence across years, sampling times, and sites. However, $\chi^{2}$ tests of dual occurrence indicated that interactions between specific pairs of pathogens in or on leaves are not likely to be major causes for overall frequency correlations. Results indicate that dematiaceous hyphomycetes typically infect forage bermudagrass on swine waste application sites in complexes rather than as individual species; that E. rostratum, C. lunata, and $B$. cynodontis are the predominant pathogens; and that frequencies of pathogens often differ significantly between locations.
\end{abstract}

Species of Bipolaris, Curvularia, Drechslera, and Exserohilum, members of a group of pathogens often referred to as "dematiaceous hyphomycetes", cause foliar, crown, and root diseases on many turf and forage grasses and small grains in the United States. Although diseases caused by some dematiaceous hyphomycetes on grasses are unique and distinct (5), most are similar in host symptomatology, disease cycles, life cycles of pathogens, and the types of damage induced $(2,19,22)$. Some dematiaceous hyphomycetous diseases are caused only by specific individual pathogens (4-6), whereas others may be associated with multiple pathogens, complexes, or individual pathogens that occur contemporaneously or sequentially in stands $(2,13,14,22)$.

Bermudagrass (Cynodon dactylon [L.] Pers.) has long been widely grown for turf (22) and as a forage crop for grazing and hay production (1) in the southeastern United States. In recent years, bermudagrass in this region also has come to be used as a receiver crop for the disposal of waste materials in concentrated swine and poultry production $(8,12)$. In this role, large quantities of wastes that are generated daily from facilities that may produce $>10,000$ hogs or $>200,000$ chickens per location are applied in liquid or solid form to bermudagrass pastures. The intention is that the growing grass will absorb high levels of phosphorus present in the animal wastes and reduce or prevent its movement into lakes, streams, and other surface waters to cause

Corresponding author: R. G. Pratt; E-mail address: rpratt@msa-msstate.ars.usda.gov

DOI: 10.1094/PHYTO-95-1183

This article is in the public domain and not copyrightable. It may be freely reprinted with customary crediting of the source. The American Phytopathological Society, 2005. eutrophic pollution $(8,12)$. Eutrophication, or over-enrichment of surface waters that leads to destruction of nearly all aquatic life, is a major form of water pollution in the United States today that has many harmful ecological and economic consequences $(11,21)$

Species of dematiaceous hyphomycetes long have been known to infect bermudagrass grown for turf in the southeastern United States. Bipolaris cynodontis (Marignoni) Shoemaker usually is considered the predominant pathogen $(2,19,22)$, but eight other species of the four genera also were associated with diseases of bermudagrass in this region prior to $2000(2,9)$. Most of these pathogens are reported to cause typical symptoms of leafspot, leaf dieback, and crown, stem, and root rot on bermudagrass and many other turf and forage grasses $(2,19)$. In recent years, most species of dematiaceous hyphomycetes previously known to infect bermudagrass $(2,9)$, and several others not previously known $(14,15)$, were found to infect and damage forage bermudagrass on sites where swine and poultry wastes were applied in Mississippi. The full range of possible symptoms was observed in infected plants on these sites, and 48 to $63 \%$ losses in forage production were estimated in samples of diseased sod taken from one swine farm where stand dieback occurred (13). These observations indicate that diseases caused by dematiaceous hyphomycetes are major factors that may limit the effectiveness of bermudagrass to grow, absorb phosphorus, and prevent eutrophic water pollution initiated from swine and poultry waste application sites in the southeastern United States.

Previous studies of diseases on forage bermudagrass in Mississippi indicated that multiple species of dematiaceous hyphomycetes are present on both swine and poultry waste application sites, and that all observed species are pathogenic (13-15). How- 
ever, the extent to which these pathogens occur individually or together in infected tissues, and their consistency or variation in occurrence over time and among locations, were not comprehensively evaluated. Therefore, this study was undertaken to identify and compare frequencies of dematiaceous hyphomycetes in symptomatic leaf tissues of forage bermudagrass on swine waste application sites in Mississippi within and across years, sampling times, and locations. Results provide the first comprehensive comparisons of frequencies of occurrence of these dematiaceous hyphomycetes on bermudagrass in the southeastern United States, and they indicate the manner and extent to which these pathogens occur individually and in complexes on this host.

\section{MATERIALS AND METHODS}

Collection of symptomatic bermudagrass leaves. Samples of symptomatic bermudagrass leaves were collected from common forage bermudagrass grown on liquid waste application sites of three commercial swine farms in Lowndes, Webster, and Chickasaw counties, MS, in 1999, 2000, and 2002. Sampling commenced in early July of each year, shortly after foliar symptoms of infection by dematiaceous hyphomycetes became common in stands. Sampling of all sites continued at approximately biweekly intervals through mid-October, for a total of eight samples from each site during each year. At each sampling time, 50 stems of bermudagrass with foliar symptoms suggestive of infection by dematiaceous hyphomycetes $(2,13,19)$ were selected at random from throughout an $\approx 1$-ha sampling area on each site. Selected stems were excised, placed in plastic bags with a moist paper towel to prevent drying, and transported to the laboratory. Samples were collected from the same 1-ha area at each site throughout the 3 years of the study.

Assay of leaves for dematiaceous hyphomycetes. Samples were stored moist at $5^{\circ} \mathrm{C}$ for up to 4 days prior to plating. From each stem, a single leaf blade with both well-developed symptoms and contiguous, healthy-appearing, green tissue was selected for assay. Blades were trimmed to a length of 4.5 to $5.0 \mathrm{~cm}$, which included primarily symptomatic tissue but also border areas with healthy-appearing tissue. Leaf blades were 2.0 to $4.0 \mathrm{~mm}$ wide, with most in the range of 2.5 to $3.5 \mathrm{~mm}$. Therefore, areas of tissue assayed for individual leaves were 90 to $200 \mathrm{~mm}^{2}$ or slightly smaller if the sample included the pointed tip. Samples of mature leaves were selected from all sites on the basis of well-developed symptoms irrespective of leaf width.

Fifty leaves from each site were sealed together loosely in a cheesecloth pouch, rinsed under running tap water for $30 \mathrm{~min}$, blotted between paper towels to remove water, swirled in $70 \%$ ethanol for 12 to $15 \mathrm{~s}$ to surface disinfest, rinsed again for $30 \mathrm{~min}$ in running tap water, blotted, and plated on $2 \%$ water with five leaf sections per 9.5 -cm-diameter plate. Leaves on agar were incubated under fluorescent plant growth lights $\left(80 \mathrm{~mol} \mathrm{~m}^{-2} \mathrm{~s}^{-1}\right)$ on a 12-h photoperiod for 10 days at 25 to $27^{\circ} \mathrm{C}$ to enable growth and sporulation of fungi from within tissue. Colonies on leaves and in surrounding agar were observed by placing open plates on the stage of an objective-lens microscope and observing surfaces at $\times 50$ or $\times 100$ for spores of dematiaceous hyphomycetes.

Identification of species of dematiaceous hyphomycetes. Species of Bipolaris, Curvularia, and Exserohilum were identified according to species concepts and descriptions, and taxonomic standards for species separations, as presented in four keys and monographs $(2,7,18,19)$. Genus name usage followed Sivanesan (18).

In the evaluation of samples, where large numbers of species identifications were required for numerous fungal colonies on leaves, identifications were based upon the presence or absence of specific morphological features or combinations of features that were considered unique for each species known to occur on bermudagrass in Mississippi. If any colonies did not clearly ex- hibit these specific features or combinations on assay plates, then colonies were transferred or spores were examined in greater detail to unequivocally establish species identity. The specific morphological features used for practical identification of each observed species on bermudagrass in this study are described in the Results section.

Statistical procedures. Data on percentages of infection of the 50 leaves collected from each site at each sampling time by each of the eight pathogen species observed in the study were compared within and across years by analysis of variance (ANOVA) using the MIXED procedure of the Statistical Analysis Software System (SAS) (SAS Institute, Cary, NC) following arcsin squareroot transformation of the percentage data. Least squares means were used to determine statistical significance. Pathogen species and sampling time were considered fixed effects in ANOVA and location was considered a random effect. Significant $(P=0.05)$ differences in frequencies of occurrence of pathogen species within and across years, and in frequencies of individual species among sampling times within years, were compared by use of Fisher's protected least significant difference test at $P=0.05$. Differences in frequencies of pathogens among locations were evaluated by the $\chi^{2}$ test using the FREQ procedure of SAS. Data on numbers of pathogen species present on individual leaves were evaluated for goodness-of-fit to Poisson distributions by the $\chi^{2}$ test (10), and correlations between frequencies of occurrence of pathogens across sampling events were evaluated by linear correlation (10). Frequencies of dual occurrence of all possible pairs of pathogens in individual leaves were evaluated for deviation from expected values by $\chi^{2}$ tests (10) in nine sampling events for most pathogen combinations.

\section{RESULTS}

Symptoms of foliar infection by dematiaceous hyphomycetes on forage bermudagrass. Symptoms consisted of dark- or red-brown, irregular necrotic flecks and lesions on leaves that were most pronounced on distal blade tissue. Commencing at tips of leaves, expanding lesions coalesced to form zones of light- to orange-brown necrosis that extended completely across blades and advanced proximally toward stems with irregular margins. Smaller necrotic areas of coalesced lesions sometimes formed ahead of the zone of advancing complete distal necrosis. Severely affected blades became completely necrotic, shriveled, and twisted as necrosis spread into sheaths. Symptoms were most severe on oldest leaves at lower positions on stems, and they were usually slight or absent on youngest, uppermost leaves.

Symptoms of foliar infection by dematiaceous hyphomycetes often were minor or sporadic during the first half of each summer growing season, but they usually became widespread by early July. Symptoms then usually were distributed generally through stands with little evidence of clustering within them. In most locations and years, foliar symptoms attributed to dematiaceous hyphomycetes continued to become more common or severe as the growing season progressed from July through October, except that they usually were minimal in regrowth that developed for several weeks following cuttings of hay at 4- to 6-week intervals. No consistent or diagnostic symptoms could be attributed to infection by individual dematiaceous hyphomycetes except for Drechslera gigantea (Heald \& F.A. Wolf) Ito. This fungus formed distinct, larger, localized brown lesions with light centers that were distributed randomly over leaves and independently of symptoms caused by the other dematiaceous hyphomycetes (4).

Identity, frequency, and diagnostic features of dematiaceous hyphomycetous pathogens on forage bermudagrass. Imprinting of freshly collected leaf samples, prior to washing and surface disinfestation, by pressing them onto agar in plates and observing agar surfaces for deposited spores, revealed few or no spores of dematiaceous hyphomycetes present on leaves initially. Growth of 
hyphae from samples and initial sporulation by dematiaceous hyphomycetes on leaf surfaces was first observed 1 to 2 days after plating. Colonies of dematiaceous hyphomycetes developed initially only from necrotic or symptomatic leaf tissue, and not from green tissue in samples until this became overgrown by both pathogens and saprophytes late in the incubation period. Colonies also never were observed to develop from preexisting spores or hyphae that might have been deposited on agar during plating of leaves. By 7 days after plating, ample sporulation by dematiaceous hyphomycetes and other fungi usually was present over most necrotic tissues and on surfaces of colonies that developed from them into surrounding agar. By 10 days after plating, colonies were present throughout agar in plates, fungal sporulation was present over most leaf surfaces, and no further growth or sporulation occurred.

Eight species of dematiaceous hyphomycetous pathogens were detected on symptomatic leaves of forage bermudagrass at the three swine waste application sites during the 3 years of this study (Table 1). Exserohilum rostratum, B. cynodontis, B. spicifera, Curvularia lunata, and $C$. geniculata were observed on all sites during all years and usually were present at moderate to high frequencies. B. stenospila also was observed on one to three sites each year but always at low frequencies $(\leq 1 \%)$. B. hawaiiensis, formerly known only from south Mississippi (14) as the northernmost point of occurrence in North America, was observed at low frequencies at all three sites during only the second and third years. B. sorokiniana was observed during only the third year of the study at low frequencies at all sites as noted (15).

Symptoms of infection by D. gigantea (4) also were observed on bermudagrass at all sites. Other potential leaf-infecting pathogens that occasionally sporulated on plated leaves, but were not quantified, were species of Nigrospora, Colletotrichum, and Fusarium.

In most instances, identification of a pathogen on a leaf sample or emanated mycelium was based upon observation of dozens to thousands of spores per leaf. The four species that sporulated most profusely (B. cynodontis, B. spicifera, C. lunata, and E. rostratum) usually could be identified immediately on the basis of their ample sporulation, in which the full range of morphological features was apparent. Four other species that sporulated less profusely (B. hawaiiensis, B. stenospila, B. sorokiniana, and $C$. geniculata) all exhibited distinctive features of spore morphology that enabled their conclusive identification on the basis of fewer conidia than in the most profusely sporulating species. Morphological features that were used routinely for the practical identification of dematiaceous hyphomycetes in mixed cultures on bermudagrass leaves are summarized as follows:

C. lunata: distinguished by profuse production of small (25 to 30 microns long), curved, asymmetrical, often bulbous or inflated, pale brown, conidia with subhyaline tip cells, a swollen third cell, and invariably three pseudosepta.

C. geniculata: sporulation less profuse than in $C$. lunata, but identification is indicated at $\times 100$ by conidia that are comparable in length to those of $C$. lunata, but are more narrow, nearly straight to crooked or curved at median points, narrowed at apices, and without a bulbous or inflated appearance. Identity is confirmed by observation at $\times 200$ or $\times 400$ of four pseudosepta in each conidium, including two closely spaced at the distal end.

B. cynodontis: profusely sporulating species with mediumsized spores that is characterized primarily by a nondescript or "generalized" Bipolaris-type morphology, with an absence of any unique or distinctive morphological features comparable to those of the other Bipolaris spp. known to occur on bermudagrass. Conidia are light brown to fuliginous, thin-walled, commonly with four to six faint pseudosepta, cylindrical to slightly curved, with broadly rounded apices, and commonly 45 to 50 microns long.

$B$. spicifera: usually immediately recognizable by dense clusters of numerous, small conidia (comparable in size to C. lunata) that are medium- to dark-olivaceous, oblong or cylindrical, with broadly rounded apices, and always tripseudoseptate. The close homogeneity in size and color of the numerous conidia of this species enables its rapid identification with a high degree of certainty at $\times 50$; identification is confirmed by universal observation of three pseudosepta in each conidium at $\times 100$ or $\times 200$.

B. hawaiiensis: this species presents the appearance at $\times 100$ of a miniaturized version of $B$. cynodontis. Sporulation is more sparse than in B. cynodontis and conidia are smaller (comparable in length to B. spicifera or $C$. lunata), darker brown, and more uniform in size and shape. Conidia also contained four or five pseudosepta that appeared to be crowded within them at narrow intervals. Conclusive identification may be made at $\times 200$ or $\times 400$ from relatively few spores on account of their highly consistent size, color, shape, and septation.

B. stenospila: this species presents the appearance of a magnified or enlarged version of $B$. cynodontis. Although technical descriptions indicate overlap with $B$. cynodontis in lengths of conidia and numbers of pseudosepta, in reality, values observed for these parameters in B. stenospila nearly always exceed the maximal values commonly observed in $B$. cynodontis. Conidia of

TABLE 1. Species of dematiaceous hyphomycetous pathogens observed on symptomatic leaves of forage bermudagrass at three swine waste application sites in Mississippi and frequencies of occurrence ${ }^{\mathrm{w}}$

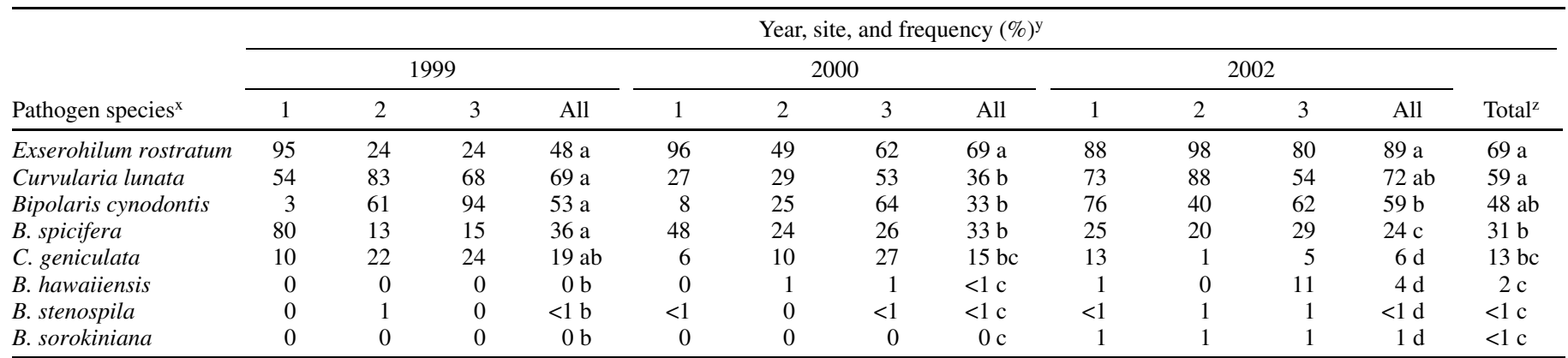

${ }^{\mathrm{w}}$ Data are percentages of 400 symptomatic leaves on which pathogens were observed. Fifty leaves were collected and assayed at each of eight sampling times per site per year. Assays were performed by incubating washed, surface-disinfested leaves on water agar under plant growth lights for 10 to 14 days and observing surfaces and emanated mycelium for sporulation by pathogens. Means within columns not followed by the same letter differ significantly at $P=0.05$ according to Fisher's protected least significant difference test as determined following analysis of variance of arcsine-square root-transformed data on percentages of occurrence.

${ }^{x}$ Drechslera gigantea also was observed on bermudagrass on all sites, but this pathogen formed distinct leaf spots that were not associated with the same necrotic tissues in which other species were observed.

${ }^{y}$ Sites 1,2, and 3 are the waste application fields of commercial swine production farms in Webster, Lowndes, and Chickasaw counties, MS, respectively.

${ }^{z}$ Percentage over all years and all sites. 
B. stenospila also are conspicuously darker brown and more curved (often banana-shaped) than conidia of B. cynodontis. Although sporulation is relatively meager, small numbers of conidia of B. stenospila are conspicuous among more numerous conidia of $B$. cynodontis due to their darker color, greater length (commonly 80 to 90 microns), more extensively curved shapes, and more numerous pseudosepta (commonly 8 to 10 ).

B. sorokiniana: although sporulation is not profuse, conidia are immediately recognizable by their large size (often $>80$ to 100 microns long), thick walls, strongly pronounced pseudosepta, rich chocolate-brown color, narrowed tips, and elongated ovoid shapes that often approximate an American football in appearance. No other species exhibits these features individually or in composite, and conclusive identification can be made on the basis of very few spores.

E. rostratum: sporulation usually is relatively profuse and distinctive. Two features that enable immediate identification, even on the basis of only a few spores observed at $\times 50$ or $\times 100$, are two thickened, terminal pseudosepta at distal and proximal ends of conidia, and the retention, at the basal end of each conidium, of the terminal portions of the conidiophore walls along with the basal septum, which is positioned within the conidiophore beyond the contour of the spore wall. No other species observed on bermudagrass exhibits these characteristics. Variable percentages of the large conidia of E. rostratum exhibit a unique "rostrate" shape (3) that also facilitates its immediate identification when this feature is present.

Numbers of species observed on individual leaves. Percentages of leaves on which different numbers of pathogens were observed for each site and year are presented in Table 2. Over all years and sites, one or more pathogen species were observed on $97 \%$ of assayed, symptomatic leaves. Of the $3 \%$ of leaves on which no pathogens were detected, most of these were collected in 2000, which was a year of severe drought, and especially on site 2 in that year, where the bermudagrass was not located under a center-pivot irrigator and did not receive frequent applications of water in the form of liquefied swine waste.

Among the $97 \%$ of assayed, symptomatic leaves on which dematiaceous hyphomycetes were observed, two or more species were observed on a majority of the leaves from all sites in all years (Table 2). During 1999 and 2002, when rainfall was normal or abundant, 75 to $95 \%$ of leaves assayed from each site had multiple pathogens; however, during the drought year of 2000, only 58 to $77 \%$ of leaves had multiple pathogens. From most leaves with multiple pathogens, two or three species were observed; however, on up to $15 \%$ of leaves from each site, four species were observed and, on up to $2 \%$ of leaves, five species were observed. None of the 3,600 leaves assayed during this study were observed to be infected by more than five species of pathogens (Table 2).

On all sites within all years, data on numbers of pathogen species present on individual leaves differed significantly $(P=$ 0.01 ) from a Poisson distribution as determined by $\chi^{2}$ tests (Table 2 ). On most sites within years, numbers of leaves infected with one, four, or five species of pathogens were fewer than expected in a Poisson distribution, and numbers infected with two or three species of pathogens exceeded numbers expected in a Poisson distribution.

Sources of variation for occurrence of pathogens. Sources of variation and their significance for tests of fixed effects within and across years are presented in Table 3 . In each year and across years, highly significant $(P<0.01)$ differences were observed in frequencies of occurrence of the eight pathogen species on the samples of 50 leaves across all sampling times and locations. No significant differences in total frequencies of pathogens (total frequencies of occurrence of all pathogens across sites) were observed among sampling times in any year or across years. However, highly significant $(P<0.01)$ interactions between pathogen species and sampling times were observed in 2 of 3 years, and

TABLE 3. Sources of variation and their significance for frequencies of occurrence of eight dematiaceous hyphomycetous pathogens on symptomatic leaves of forage bermudagrass at three swine waste application sites in Mississippi ${ }^{\mathrm{y}}$

\begin{tabular}{lrrr}
\hline Year, source of variation & df & $F^{\mathrm{z}}$ & $P>F$ \\
\hline 1999 & 7 & 4.45 & 0.0085 \\
Pathogens & 7 & 1.88 & 0.0787 \\
Sampling times & 49 & 1.85 & 0.0040 \\
Pathogens $\times$ sampling times & & & \\
2000 & 7 & 10.13 & 0.0002 \\
Pathogens & 7 & 1.18 & 0.3202 \\
Sampling times & 49 & 1.16 & 0.2632 \\
Pathogens $\times$ sampling times & 7 & 34.28 & $<0.0001$ \\
2002 & 7 & 1.12 & 0.3570 \\
Pathogens & 49 & 2.04 & 0.0011 \\
Sampling times & & & \\
Pathogens $\times$ sampling times & 7 & 17.01 & $<0.0001$ \\
All & 7 & 1.37 & 0.1212 \\
Pathogens & 49 & 1.20 & 0.0791 \\
Sampling times & & & \\
Pathogens $\times$ sampling times & & & \\
\hline
\end{tabular}

y Data used to evaluate variation consist of the frequencies of occurrence of each of eight fungal pathogens on 50 symptomatic leaves of bermudagrass that were assayed from each of three sites at eight sampling times per year during 3 years. Total observations were 192 per year and 576 for all 3 years.

${ }^{\mathrm{z}}$ Determined by analysis of variance following arcsine-square root transformation of data on percentages of leaves infected.

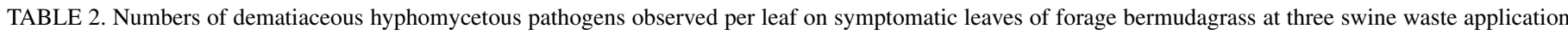
sites in Mississippi

\begin{tabular}{|c|c|c|c|c|c|c|c|c|c|}
\hline \multirow[b]{3}{*}{ No. of pathogens ${ }^{y}$} & \multicolumn{9}{|c|}{ Year, location, and percentage of leaves ${ }^{\mathrm{z}}$} \\
\hline & \multicolumn{3}{|c|}{1999} & \multicolumn{3}{|c|}{2000} & \multicolumn{3}{|c|}{2002} \\
\hline & Site 1 & Site 2 & Site 3 & Site 1 & Site 2 & Site 3 & Site 1 & Site 2 & Site 3 \\
\hline 0 & $<1$ & 2 & 3 & 1 & 1 & 7 & 3 & 0 & $<1$ \\
\hline 1 & $13(24)$ & $23(30)$ & $19(26)$ & $32(35)$ & 41 (39) & $20(27)$ & $10(21)$ & $5(22)$ & $14(24)$ \\
\hline 2 & $36(30)$ & $38(30)$ & $37(31)$ & $50(32)$ & $29(33)$ & $35(33)$ & $27(28)$ & $46(30)$ & $34(30)$ \\
\hline 3 & $44(24)$ & $27(23)$ & $33(24)$ & $15(20)$ & $11(18)$ & $25(27)$ & $50(25)$ & $38(25)$ & $35(25)$ \\
\hline 4 & 7 (15) & $6(12)$ & $6(13)$ & $2(9)$ & $2(7)$ & 14 (16) & $14(17)$ & $10(16)$ & $15(15)$ \\
\hline 5 & $0(7)$ & $0(5)$ & $2(6)$ & $<1(4)$ & $0(3)$ & $2(7)$ & $1(10)$ & $<1(8)$ & $1(7)$ \\
\hline Mean & 2.45 & 2.04 & 2.26 & 1.85 & 1.40 & 2.31 & 2.48 & 2.51 & 2.52 \\
\hline
\end{tabular}

y Number of species of dematiaceous hyphomycetes observed on individual leaves. No individual leaves assayed positive for more than five species.

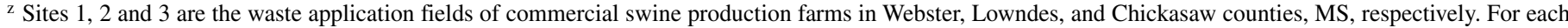
column, data not in parentheses are percentages of 400 symptomatic leaves. Fifty leaves were collected and assayed at each of eight sampling times per site per year. Assays were performed by incubating washed, surface-disinfested leaves on water agar under plant growth lights for 10 to 14 days and observing surfaces and emanated mycelium for sporulation by pathogens. Numbers in parentheses are percentages expected for a Poisson distribution. Numbers of pathogens observed on leaves differed significantly $(P=0.01)$ from Poisson distributions on all sites in all years. 
significant $(P=0.05)$ interactions between pathogen species and sampling times also were observed across years. The significant pathogen-sampling time interactions indicated that differences in frequency of some pathogen species varied among sampling times across locations, whereas differences in frequency of other species did not vary among sampling times.

Differences in frequency of pathogen species. Pathogen species differed significantly $(P=0.05)$ in their frequencies of occurrence within and across years (Table 1$)$. E. rostratum was the species most frequently observed during 2000 and 2002, and C. lunata was most frequent during 1999. Frequencies of occurrence of these two species, and of B. cynodontis, usually did not differ significantly from one another except during the drought year of 2000, when E. rostratum occurred at higher frequencies than all other pathogens. B. spicifera and C. geniculata usually were intermediate in frequency of occurrence, but their frequencies were not significantly less than for the three most common species, except during 2002.

$B$. hawaiiensis, B. stenospila, and B. sorokiniana were the most infrequently occurring species, and no significant differences in frequency were observed among them. Their frequencies were significantly less than for all other species in all years and across years except for $C$. geniculata in 2000 (Table 1).

Differences in frequency of pathogens between sampling times. No significant differences in total frequencies of occurrence of the eight pathogens among sampling times within a year were observed (Table 3$)$. However, significant $(P=0.05)$ interactions between pathogen species and sampling times for frequencies of occurrence were observed in 1999 and 2002. Tests for those years indicated significant differences in the frequency of E. rostratum, B. cynodontis, and C. lunata among sampling times across all sites in 1999, and of B. cynodontis and C. lunata in 2002. In addition, significant differences in the frequency of B. spicifera among sampling times were indicated in 2000 even though the total pathogen-sampling time interaction was not significant for that year (Table 4).

In most instances, significant differences in the frequency of occurrence of individual pathogen species among sampling times within years represented increases in frequency from the first sampling times in July to intermediate or final times in August, September, and October (Table 4). However, for B. cynodontis in 2002, the maximal frequency occurred at the first sampling time in early July, and frequencies were significantly smaller at most subsequent sampling times.

Differences in frequency of pathogens between locations. Location was considered a random effect in the statistical model and was not evaluated as a source of variation in ANOVA. However, $\chi^{2}$ tests for significant $(P=0.05)$ differences in the frequency of individual pathogens between locations revealed that, for each of the five most common pathogens in a majority of the sampling times, the frequencies of occurrence differed significantly among locations (Table 5). For B. cynodontis, frequencies differed significantly among locations during all 24 sampling times.

Among the sampling times in which significant differences in the frequency of individual pathogens occurred among locations, maximum frequencies generally occurred at the same location over time for each pathogen. Maximum frequencies of $E$. rostratum and $B$. spicifera occurred predominantly at site 1 , the maximum frequency of $C$. lunata occurred predominantly at site 2 , and maximum frequencies of $B$. cynodontis and $C$. geniculata occurred predominantly at site 3 (Table 5).

TABLE 4. Frequency of occurrence of dematiaceous hyphomycetous pathogens on symptomatic leaves of forage bermudagrass at swine waste application sites in Mississippi at different sampling times within years

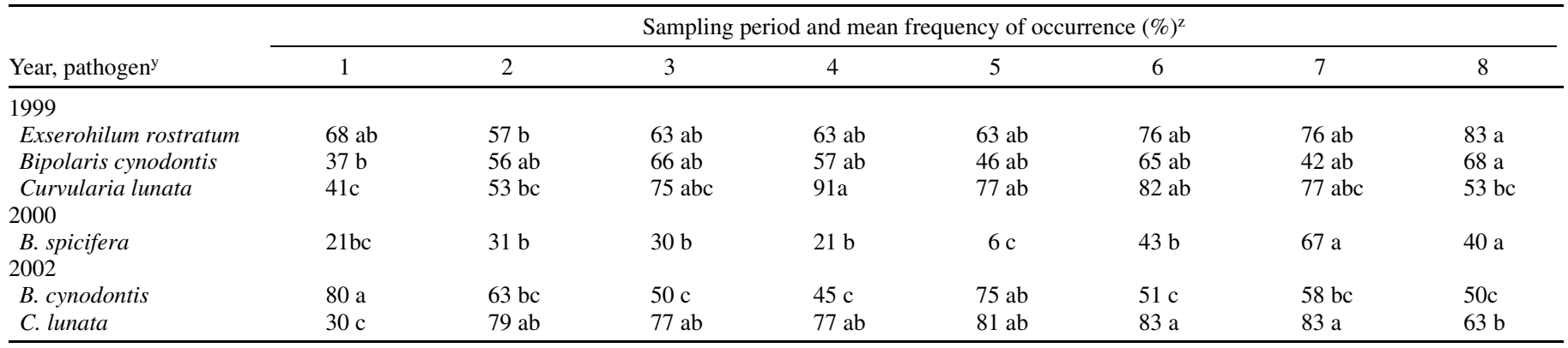

${ }^{\mathrm{y}}$ Pathogen species are listed for which significant $(P=0.05)$ pathogen-sampling time interactions for frequency of occurrence were indicated in tests of effect slices. Pathogens not listed did not exhibit significant differences in frequency of occurrence between sampling times within years.

${ }^{z}$ Sampling periods 1 to 8 commenced in early July of each year and continued until mid-October at approximate 2-week intervals. Data are mean frequencies of occurrence in 150 sampled leaves across locations for each sampling period. Means within rows not followed by the same letter differ significantly $(P=0.05)$ according to Fisher's protected least significant difference test.

TABLE 5. Numbers of sampling times in which frequencies of pathogens differed significantly between locations and in which maximal frequencies occurred at each location

\begin{tabular}{lcrrr}
\hline & & \multicolumn{2}{c}{ No. of times maximal frequency at each location $^{\mathrm{y}}$} \\
\cline { 3 - 5 } Pathogen & No. of times different between locations ${ }^{\mathrm{x}}$ & Site 1 & Site 2 \\
\hline Exserohilum rostratum & 20 & 14 & 4 & 2 \\
Bipolaris cynodontis & 24 & 7 & 15 & 12 \\
Curvularia lunata & 22 & 2 & 1 & 5 \\
B. spicifera & 18 & 14 & 4 & 3 \\
C. geniculata & 14 & 0 & 0 & 0 \\
B. hawaiiensis & 0 & 0 & 0 & 0 \\
B. stenospila & 1 & 1 & 0 & 0 \\
B. sorokiniana & 0 & 0 & 0 & \\
\hline
\end{tabular}

x Sampling times in which frequencies differed significantly between locations. Significance $(P=0.05)$ of differences in frequency of occurrence of each pathogen between locations was determined by the $\chi^{2}$ test for each sampling time. Maximal sampling times at which significant differences could occur between locations $=24$ (eight sampling times per year $\times 3$ years).

y Sampling times with significant differences in which maximal frequency occurred at each location.

${ }^{z}$ Total for locations is 25 because the same maximal frequency occurred at two locations during one sampling time. 
Correlations between frequencies of occurrence of pathogens. Linear correlations between frequencies of occurrence for all 28 possible pairs of pathogens in the samples of 50 symptomatic bermudagrass leaves were evaluated across all 72 sampling events $(3$ years $\times$ eight sampling times $\times$ three locations). Significant $(P=0.05)$ or highly significant $(P=0.01)$ correlations were observed for 9 of the 28 pairs (Table 6). Six of these nine correlations were positive and three were negative. Seven of the nine significant correlations involved E. rostratum or B. spicifera, and frequencies of these two species were positively correlated with each other (Table 6).

Frequencies of pairs of pathogens in individual infected leaves. Frequencies of dual occurrence of pairs of pathogens in individual infected leaves were evaluated for deviation from expected values by $\chi^{2}$ tests in nine sampling events for most species. For the group of five most frequent species (Table 1), a single sampling time was selected randomly for each year, and frequencies of dual occurrence of each species with other members the group were evaluated at each site during that sampling time, for a total of nine sampling events over 3 years. Sampling times selected were week 5 in 1999, week 3 in 2000, and week 8 in 2002. For the three least frequent species (Table 1), frequencies of dual occurrence with other pathogens were evaluated only in sampling events in which positive occurrence was recorded. These sampling events were selected to include as many years and sampling times as possible. They included nine sampling events for B. hawaiiensis in 2000 and 2002, nine events for $B$. stenospila over all years, and seven events for B. sorokiniana in 2002.

For each pair of pathogens, numbers of sampling events in which frequencies of dual occurrence differed significantly $(P=$ $0.05)$ from values expected by the $\chi^{2}$ test are presented in Table 7. Among 216 total sampling events evaluated for the 28 pathogen pairs, significant deviations from expected frequencies of dual occurrence were observed in only $7(3 \%)$. For all pairs of pathogens, significant deviations were not observed in more than one in nine events. These deviations represented two increases and five decreases from expected frequencies of dual occurrence (Table 7).

\section{DISCUSSION}

Results of this study reveal patterns of both major and minor variation in occurrence of dematiaceous hyphomycetes on forage bermudagrass on swine waste application sites in Mississippi. One pattern of major variation was in numbers of pathogens present in individual, symptomatic leaf tissues. Although all of the pathogens observed here were reported previously on bermudagrass, most literature has presented them as individual pathogens that cause specific diseases. Examples include sooty blotch caused by $B$. cynodontis $(2,19,22)$, stem and crown necrosis caused by B. spicifera $(2,19)$, and Curvularia blight caused by Curvularia spp. $(2,19)$. However, Couch (2) also noted that simultaneous infection by these and other pathogens occurs commonly, and that additional research is needed to more clearly characterize diseases incited by each species.

In this study, on all sites and in all years, two to five pathogens were observed to sporulate on a majority of symptomatic leaves, and usually $>75 \%$ of symptomatic leaves assayed positive for multiple pathogens (Table 2). Because pathogenicity has been proven for all of these species on bermudagrass (13-16), these results indicate that the dematiaceous hyphomycetes occur primarily as complexes (23) on forage bermudagrass rather than as individual pathogens. Whether the multiple pathogens present in these complexes interact additively or synergistically to increase symptoms in the host (17), or whether cross-protection may result from mixed infections of host tissues (18), is not yet established.

TABLE 6. Correlation coefficients for pairwise frequencies of occurrence of eight species of dematiaceous hyphomycetes on leaves of forage bermudagrass over years, sampling times, and locations ${ }^{\mathrm{y}}$

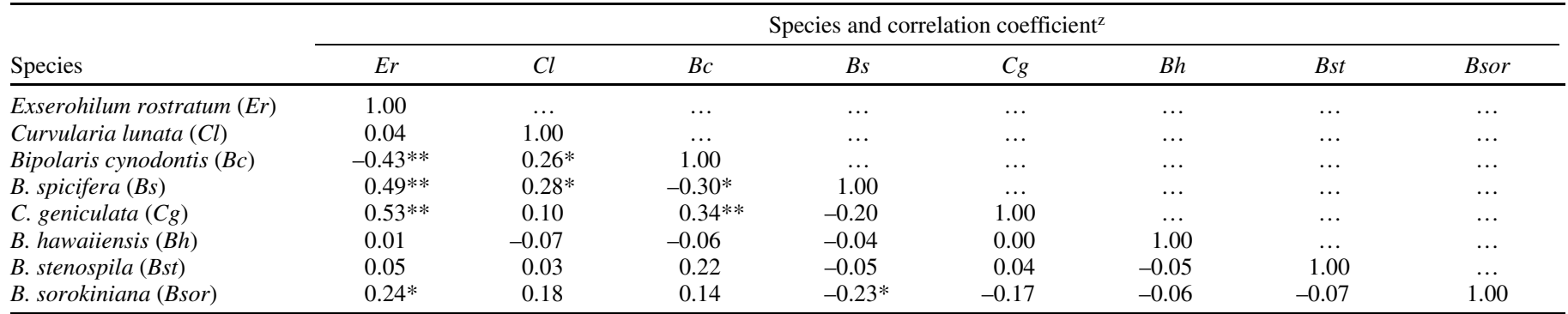

y Each correlation is based upon mean frequencies of occurrence of two species of dematiaceous hyphomycetes on 50 bermudagrass leaf samples collected at each of 72 sampling events ( 3 years $\times$ eight sampling times $\times$ three locations).

${ }^{\mathrm{z}}$ Genus and species abbreviations as given in left column; * and $* *=$ significant at $P=0.05$ and 0.01 , respectively.

TABLE 7. Numbers of selected sampling events in which frequencies of dual occurrence of pairs of pathogens in individual bermudagrass leaves differed significantly from expected frequencies ${ }^{\mathrm{y}}$

\begin{tabular}{|c|c|c|c|c|c|c|c|}
\hline \multirow[b]{2}{*}{ Species } & \multicolumn{7}{|c|}{ Number of events in which frequency differed significantly ${ }^{\mathrm{z}}$} \\
\hline & Er & $\mathrm{Cl}$ & $B c$ & Bs & $\mathrm{Cg}$ & $B h$ & Bst \\
\hline Exserohilum rostratum $(E r)$ & $\ldots$ & $\ldots$ & $\ldots$ & $\ldots$ & $\ldots$ & $\ldots$ & $\ldots$ \\
\hline B. spicifera $(B s)$ & 0 & $1(+)$ & $1(+)$ & $\ldots$ & $\ldots$ & $\ldots$ & $\ldots$ \\
\hline C. geniculata $(\mathrm{Cg})$ & 0 & 0 & 0 & 0 & $\ldots$ & $\ldots$ & $\ldots$ \\
\hline B. hawaiiensis $(B h)$ & 0 & $1(-)$ & $1(-)$ & $1(-)$ & 0 & $\ldots$ & $\ldots$ \\
\hline
\end{tabular}

y Data are numbers of sampling events out of seven or nine total in which frequencies of dual occurrence of pathogens in 50 symptomatic bermudagrass leaves differed significantly $(P=0.05)$ from expected frequencies according to the $\chi^{2}$ test. Data for pathogen pairs with $B$. sorokiniana are based on seven selected sampling events from 1 year; data for all other pathogen pairs are based on nine sampling events from 2 or 3 years.

${ }^{\mathrm{z}}$ Species and number of sampling events in which the frequency of dual occurrence differed significantly from expected frequency. Genus and species abbreviations as given in left column; $+=$ frequency of dual occurrence greater than expected and $-=$ frequency less than expected. 
Mean numbers of pathogens observed per leaf ranged from a low of 1.4 on one site during the drought year of 2000 to $>2.0$ at all sites in the 2 years with more average rainfall. It is suggested from these results that the diversity of pathogens in infected bermudagrass leaf tissue may increase during relatively wet years and decrease during periods of drought. If so, then species diversity in complexes of dematiaceous hyphomycetes on bermudagrass may be favored under conditions that enable sporulation, splash dispersal, spore germination, and infection of leaf tissues by conidia.

A second pattern of major variation in these results was that the dematiaceous hyphomycetes occurred at very different frequencies on bermudagrass and could be grouped into major, intermediate, and minor species on that basis. Across sites and years, E. rostratum, $C$. lunata, and B. cynodontis were the three major species, and these always were significantly more frequent than the three minor species, B. hawaiiensis, B. stenospila, and B. sorokiniana (Table 1). Two other species, B. spicifera and $C$. geniculata, usually were intermediate in frequency. These groupings of pathogens usually were consistent across years; the only major exception was that relative frequencies of B. cynodontis and $B$. spicifera shifted completely between the first and third years of the study at site 1 (Table 1). Shifts in occurrence of minor species also were represented by the first appearance of $B$. sorokiniana at all sites during the final year of the study, as well as the first appearance of $B$. hawaiiensis at all sites during the final 2 years and its rapid increase in frequency at site 3 (Table 1).

One novel result of this study was the demonstration that $B$. cynodontis, which usually is considered the major dematiaceous hyphomycete on bermudagrass $(2,19,22)$, was not always the most frequent pathogen of this group. Although it was clearly one of the major pathogens on most sites and in most years, its frequency across sites was significantly less than for $E$. rostratum in 2 of 3 years, and it was only the fourth or fifth most frequent pathogen at site 1 in 1999 and 2000 (Table 1).

Two additional patterns of variation observed in this study were in the frequency of individual pathogens among locations and sampling times. Differences among locations were most important because these were observed with all five of the most common pathogens. Although E. rostratum, C. lunata, and B. cynodontis usually were the major pathogens at all sites, their frequencies of occurrence still differed significantly among sites at most sampling times, and maximum frequencies tended to occur consistently at specific sites. For example, for 2 years of the study, maximum frequencies of E. rostratum and B. spicifera occurred primarily at site $1, C$. lunata at site 2 , and B. cynodontis at site 3 . These results indicate that the complexes of dematiaceous hyphomycetes on forage bermudagrass may differ among sites or years even when the same species are present as major components.

Differences in frequencies of some individual pathogens among sampling times within years also represented a significant pattern of variation observed in this study. Significant differences in frequency among sampling times across sites were observed for only one to three of the eight pathogens each year. When such differences did occur, the trend usually was toward increased frequencies from early to mid- or late season. Despite this significant variability, however, results still indicate that sampling during any of the eight times used in this study would give a reasonably accurate representation of the pathogens present on a particular site and their relative frequencies. Drastic differences in pathogen occurrence among sampling times within years would not be expected on the basis of these observations.

Observations made during this and previous studies (13-15) indicate with a high degree of certainty that data presented represent pathogens that grew and sporulated from within plated, symptomatic bermudagrass leaf tissues, and not from contaminating spores that were present on leaf surfaces initially or deposited there during washing. Samples were collected from erect stems of bermudagrass during relatively dry periods when plants were exposed to sunlight and wind. When newly collected leaf samples were imprinted on agar prior to washing and plating, few spores of dematiaceous hyphomycetes were observed initially. When samples were examined microscopically 1 to 3 days after plating on agar, initial hyphal growth and sporulation by dematiaceous hyphomycetes always originated from within necrotic or symptomatic leaf tissues. Colonies never were observed to originate from green tissues within samples, where some contaminating spores would have been deposited if these had been present, or from spores or hyphae on agar external to leaves. These observations indicate that data represent pathogens that were present within the symptomatic leaf tissues rather than on their surfaces. If any potentially contaminating spores had been present on leaves initially, it is likely that these would have been killed during surface disinfestation or removed during the extensive washing of samples under running water that preceded and followed it. Longer periods of disinfestation of samples in ethanol, or the use of bleach solutions, were not employed in order to avoid excessive penetration of the thin, delicate leaves of bermudagrass and death of pathogens within them.

Control of diseases caused by dematiaceous hyphomycetes on forage bermudagrass likely will require breeding for disease resistance. Results of this study, which indicate that these diseases occur primarily as complexes of major and minor pathogens (23), are directly relevant to this goal. A major question that needs to be resolved is whether quantitative host resistance, as is known to be expressed against $E$. rostratum in excised leaves and whole plants of bermudagrass (16), also is effective against other major or minor pathogens. It also would be desirable to characterize the nature of interactions involving pathogens in bermudagrass leaf tissue, and to clearly establish whether synergism, additivity, or cross-protection in symptom development result from infection by the multiple pathogens observed in these complexes in the southeastern United States.

Although it was not an objective of this study to determine the nature of interactions between dematiaceous hyphomycetes in bermudagrass leaves, the nonrandom distributions of numbers of pathogens present in infected leaf tissues may have resulted from deleterious interactions between them. On most sites in most years, more leaves were infected with two or three pathogens than would be expected on the basis of a Poisson distribution, and fewer were infected with one, four, or five pathogens. These skewed distributions may have resulted from competition between pathogens for infection sites at tips of leaves, where symptoms usually are initiated; from cross-protection induced in the host following initial infection by one to three pathogens (20); or from disparities in amounts of inoculum available to initiate infection.

For 9 of 28 possible pairs of pathogens, significant correlations in frequencies of occurrence in leaves of bermudagrass over years, sampling times, and locations (72 sampling events) were observed. Six significant correlations were positive and three were negative. Seven of the significant correlations involved either E. rostratum or B. spicifera, and these two species were highly significantly correlated with each other. Both $E$. rostratum and $B$. spicifera also were negatively correlated with $B$. cynodontis. $C$. lunata, one of the most commonly occurring species, was positively correlated with both $B$. cynodontis and $B$. spicifera. These results suggest that $E$. rostratum and $B$. spicifera represent two pathogens that commonly occur together or that interact positively, and that both occur under different conditions than B. cynodontis or interact negatively with it. In contract, C. lunata appears to occur independently of these two groups because its frequencies of occurrence were significantly correlated with those of both $B$. spicifera and $B$. cynodontis. For the three most infrequent species, B. hawaiiensis, B. stenospila, and B. sorokiniana, correlation coefficients nearly always were low and nonsignificant in pairings with each other and with the more frequent species. 
The observed positive and negative correlations in frequency of occurrence of pathogens could be the result of broad similarities or differences in their responses to environmental conditions; to their co-occurrence or segregation in space and time (sites, years, and sampling times); or to interactions between pathogens on or in infected leaves. Results of $\chi^{2}$ tests for frequencies of dual occurrence of pathogens in individual leaves (Table 7), however, indicate that interactions between specific pairs of pathogens on or in infected leaves are unlikely to be important causes for overall positive or negative correlations. For all pairs of pathogens, significant departures from expected frequencies of dual occurrence were observed in only $3 \%$ of 216 sampling events evaluated. For all individual pairs of pathogens, significant departures from expected frequencies of dual occurrence were not observed in more than $11 \%$ of sampling events. These results indicate that interactions between specific pathogens that affect their dual occurrence on or in leaves are exceptions rather than the rule. Therefore, significant correlations in overall frequencies of occurrence (Table 6) are more likely due to responses of pathogens to broad environmental conditions, or to their co-occurrence or segregation in space and time, than to interactions between specific pathogens in or on infected leaves.

Further studies are needed to determine whether complexes of dematiaceous hyphomycetous pathogens, similar to those observed on forage bermudagrass on swine waste application sites, also occur on bermudagrass grown for turf and on forage bermudagrass grown for grazing or hay without applied animal wastes.

\section{ACKNOWLEDGMENTS}

I thank C. Meriwhether, J. Vetzel, G. Kimmel, S. Wallace, and J. Davis for assistance with assay of samples; K. Kennedy and J. Perry for assistance with data tabulation; and P. D. Gerard, Department of Experimental Statistics, Mississippi State University, for performing statistical analyses and assisting in their interpretation.

\section{LITERATURE CITED}

1. Burton, G. W., and Hanna, W. W. 1985. Bermudagrass. Pages 247-254 in: Forages: The Science of Grassland Agriculture, 4th ed. M. E. Heath, R. L. Barnes, and D. S. Metcalfe, eds. Iowa State University Press, Ames.

2. Couch, H. B. 1995. Diseases of Turfgrasses. Krieger Publishing Company, Malabar, FL.

3. Drechsler, C. 1923. Some graminicolous species of Helminthosporium. I. J. Agric. Res. 24:641-740.
4. Drechsler, C. 1929. Occurrence of the zonate-eyespot fungus, Helminthosporium giganteum, on some additional grasses. J. Agric. Res. 39:129-135.

5. Drechsler, C. 1935. A leafspot of bentgrass caused by Helminthosporium erythrospilum n. sp. Phytopathology 25:344-361.

6. Duczek, L. J. 1997. Infection of wheat and barley by Bipolaris sorokiniana during early growth stages and effects on leaf area. Can. J. Plant Pathol. 19:293-296.

7. Ellis, M. B. 1971. Dematiaceous Hyphomycetes. Commonwealth Mycological Institute, Kew, Surrey, UK.

8. Evers, G. W. 1999. Comparison of broiler poultry litter and commercial fertilizer for Coastal bermudagrass production in the southeastern U.S. J. Sustain. Agric. 12:55-77.

9. Farr, D. F., Bills, G. F, Chamuris, G. P., and Rossman, A. Y. 1988. Fungi on Plants and Plant Products in the United States. The American Phytopathological Society, St. Paul, MN.

10. Mead, R., Curnow, R. N., and Hasted, A. M. 1993. Statistical Methods in Agriculture and Experimental Biology, 2nd ed. Chapman \& Hall, New York.

11. Pierzynski, G. M., Sims, J. T., and Vance, G. H. 2000. Soils and Environmental Quality. CRC Press, Boca Raton, FL.

12. Poore, M., and Green, J. 1996. Forage systems utilizing swine effluent: Dream...or nightmare? Proc. South. Pasture Forage Crop Imp. Conf. 52:109-116.

13. Pratt, R. G. 2000. Diseases caused by dematiaceous fungal pathogens as potential limiting factors for production of bermudagrass on swine effluent application sites. Agron. J. 92:512-517.

14. Pratt, R. G. 2001. Occurrence and virulence of Bipolaris hawaiiensis on bermudagrass (Cynodon dactylon) on poultry waste application sites in Mississippi. Plant Dis. 85:1206.

15. Pratt, R. G. 2003. First report of infection of bermudagrass by Bipolaris sorokiniana in the southeastern USA. Plant Dis. 87:1265.

16. Pratt, R. G. 2003. An excised-leaf inoculation technique for evaluating host-pathogen interactions and quantitative resistance of bermudagrass genotypes to dematiaceous hyphomycetes. Phytopathology 93:1565-1571.

17. Shurtleff, M. C., and Averre, C. W., III. 1997. Glossary of Plant-Pathological Terms. The American Phytopathological Society, St. Paul, MN.

18. Sivanesan, A. 1987. Graminicolous species of Bipolaris, Curvularia, Drechslera Exserohilum and their teleomorphs. Mycol. Pap. No. 158. CAB International Mycological Institute, Kew, Surrey, England.

19. Smiley, R. W., Dernoeden, R. H., and Clarke, B. B. 1992. Compendium of Turfgrass Diseases. The American Phytopathological Society, St. Paul, MN.

20. Tolin, S. A. 2001. Cross-protection. Pages 261-264 in: Encyclopedia of Plant Pathology, Vol. I. O. C. Maloy and T. D. Murray, eds. John Wiley \& Sons, New York.

21. United States Environmental Protection Agency. 1995. National Water Quality Inventory. 1994 Report to Congress. USEPA Office of Water, Washington, DC.

22. Vargas, J. M., Jr. 1994. Management of Turfgrass Diseases. CRC Press, Boca Raton, FL.

23. Wallace, H. R. 1978. The diagnosis of plant diseases of complex etiology. Annu. Rev. Phytopathol. 16:379-402. 